\title{
Familial Congenital Hypothyroidism Due to Inactivating Mutation of the Thyrotropin Receptor Causing Profound Hypoplasia of the Thyroid Gland
}

\author{
Marc J. Abramowicz, ${ }^{\star}$ Laurence Duprez, ${ }^{\ddagger}$ Jasmine Parma, ${ }^{\star}$ Gilbert Vassart, ${ }^{\star \S}$ and Claudine Heinrichs ${ }^{\ddagger}$ \\ *Service de Génétique, Hôpital Erasme, 1070 Brussels; ${ }^{\ddagger}$ Département de Pédiatrie, Hôpital Universitaire des Enfants Reine Fabiola, \\ 1020 Brussels; and ${ }^{\S}$ Institut de Recherche Interdisciplinaire en Biologie Humaine et Nucléaire (IRIBHN), Free University of Brussels \\ (ULB), 1070 Brussels, Belgium
}

\begin{abstract}
Thyroid gland agenesis is the most common cause of congenital hypothyroidism and is usually sporadic. We investigated a brother and sister from consanguineous parents, ascertained through systematic newborn screening, and initially diagnosed with thyroid agenesis. Careful cervical ultrasonography in both patients revealed a very hypoplastic thyroid gland. By direct sequencing of the thyrotropin receptor gene, we identified the substitution of threonine in place of a highly conserved alanine at position 553 , in the fourth predicted transmembrane domain. The mutation was found homozygous in the affected siblings, and heterozygous in both parents and two unaffected siblings. Functional analysis in transfected COS-7 cells showed that it resulted in extremely low expression at the cell surface as compared with the wild-type receptor, in spite of an apparently normal intracellular synthesis. The small amount of mutated receptor expressed at the surface of transfected cells bound thyrotropin with normal affinity and responded in terms of cAMP production, but the in vivo significance of these data from overexpressed receptor in transfected cells is unclear. Of note, blood thyroglobulin was unexpectedly elevated in the patients at the time of diagnosis, a finding that might prove useful in refining etiologies of congenital hypothyroidism. (J. Clin. Invest. 1997. 99:3018-3024.) Key words: thyrotropin receptor - congenital hypothyroidism • thyroglobulin $\bullet$ thyroid agenesis
\end{abstract}

\section{Introduction}

The pituitary glycoprotein hormone thyrotropin $(\mathrm{TSH})^{1}$ stimulates growth, differentiation, and function of the thyroid gland, and these effects are mimicked by cAMP agonists (1). TSH acts on the thyroid follicular cell through a specific receptor coupled to $G$ proteins, whose hydropathy profile (2-5) displays a characteristic serpentine structure with seven trans-

Address correspondence to Marc Abramowicz, Service de Génétique, Hôpital Universitaire Erasme, 808 Route de Lennik, B-1070 Bruxelles, Belgium. Phone: 32-2-555.6430; FAX: 32-2-555.6440; E-mail: marcabra@resulb.ulb.ac.be

1. Abbreviations used in this paper: IP, inositolphosphate; KRH, Krebs-Ringer-Hepes buffer; SCA, specific constitutive activity; $\mathrm{T}_{4}$, thyroxine; TG, thyroglobulin; TPO, thyroid peroxidase; TSH, thyrotropin; $\mathrm{TSHr}$, thyrotropin receptor.

J. Clin. Invest.

(C) The American Society for Clinical Investigation, Inc.

0021-9738/97/06/3018/07 \$2.00

Volume 99, Number 12, June 1997, 3018-3024 membrane domains. Together with the other glycoprotein hormone receptors, $\mathrm{LH} / \mathrm{CG}$ and $\mathrm{FSH}$, the TSH receptor (TSHr) also presents, in its aminoterminal half, a large extracellular domain involved in hormone binding. The TSHr gene contains nine introns, with exon 10 coding for the entire serpentine structure (6). Besides stimulation of the cAMP cascade, the TSHr is capable of stimulating the phospholipase C-diacylglycerol-phosphatidylinositol pathway at higher concentrations of TSH, at least in man, and these effects are mediated by Gs and Gq proteins, respectively (1). In functional studies, the TSHr displays a significant level of spontaneous activity (i.e., stimulation of second messenger production in the absence of ligand) in experimental conditions where other $G$ proteincoupled receptors are essentially silent (7-10). Mutations causing constitutive activation of the receptor have been found at the somatic level in hyperfunctioning thyroid adenomas (hot nodules) $(7,8)$, and at the germline level in familial nonautoimmune thyroid hyperplasia, a very rare condition (9). Reciprocally, inactivating mutations of the receptor have recently been described in patients with TSH resistance $(11,12)$ (see below).

Congenital hypothyroidism affects 1 in 4,000 newborns (13). Early thyroid hormone replacement therapy prevents the growth and development delay that develop postnatally in untreated patients, and systematic newborn blood screens for high TSH and/or low thyroxine $\left(\mathrm{T}_{4}\right)$ have been implemented in most western countries. The majority of cases of congenital hypothyroidism are sporadic and are due to thyroid gland agenesis (athyrosis), or dysgenesis (ectopic and hypoplastic gland). These cases are attributed to a deficient embryogenesis of the thyroid; they do not show a clear tendency to recur within families of affected children and are believed to result from nongenetic causes, like environmental insults or stochastic events early in embryogenesis. A minority of congenital hypothyroidism cases, perhaps $10 \%$, result from inborn errors of thyroid hormonogenesis, and show Mendelian inheritance, almost always of the autosomal recessive type (1). Homozygous or compound heterozygous mutations of the thyroglobulin (TG) gene, and of the thyroid peroxidase (TPO) gene, have been described in such families. In untreated patients, the increase in blood TSH activity often results in goiter, which may be present at birth (14).

It is expected that one subtype of inborn errors, if inactivating the TSHr, will not result in goiter, and instead resemble thyroid agenesis, except for showing autosomal recessive inheritance. A mouse strain called hyt/hyt presents with inherited autosomal recessive hypothyroidism and a hypoplastic gland (15). The affected mice were shown to harbor a homozygous mutation of the murine Tshr gene (16) causing defective TSH binding (17). In man, the concept of TSH unresponsiveness has been validated by clinical descriptions of patients (18, 19) and families (20) that fit the expected phenotype of low triiodothyronine and $\mathrm{T}_{4}$, and thyroid gland hypoplasia, in spite of 
high circulating levels of bioactive TSH. With the cloning of the human TSHr gene (3-5), molecular analysis of such cases became possible, but the search for mutations remained unsuccessful in previous studies (21). Recently, one patient with sporadic congenital hypothyroidism was shown to be a compound heterozygote for presumably inactivating mutations of the $\mathrm{TSHr}$ gene (22). On the other hand, compound heterozygosity for functionally tested, inactivating $\mathrm{TSHr}$ mutations was identified in siblings with resistance (i.e., partial unresponsiveness) to TSH without overt hypothyroidism $(11,12)$.

In this report, we describe a familial case of TSH unresponsiveness with congenital hypothyroidism due to a homozygous inactivating mutation causing very low expression of the TSHr at the cell surface, and profound thyroid hypoplasia.

\section{Methods}

Patients. Congenital hypothyroidism was identified through systematic screening on the fourth day of life in a boy whose blood spot TSH was $>130 \mathrm{mU} / \mathrm{liter}$, and serum $\mathrm{T}_{4}$ was low at $1.2 \mu \mathrm{g} / \mathrm{dl}$. The pregnancy had lasted $41 \mathrm{wk}$, and a cesarean section was performed because of transverse presentation. The birth weight was $4.30 \mathrm{~kg}$, length $51 \mathrm{~cm}$, and head circumference $41.7 \mathrm{~cm}$. Physical examination and ${ }^{99 \mathrm{~m}} \mathrm{Tc}$ scintigraphy failed to demonstrate the presence of thyroid tissue, and the patient was given a diagnosis of athyrosis. $\mathrm{T}_{4}$ therapy was initiated on the 9th d of life, and the neonatal course was otherwise uneventful. The family history (Fig. 1) revealed that the parents were second cousins, and that congenital hypothyroidism was previously diagnosed in a sister through an abnormal neonatal screen that showed a blood spot TSH of $490 \mathrm{mU} /$ liter, along with a low free $\mathrm{T}_{4}$ $(0.37 \mathrm{ng} / \mathrm{dl})$. She was born by standard vaginal delivery after an uneventful 41-wk pregnancy with a birth weight of $3.95 \mathrm{~kg}$, length of 53 $\mathrm{cm}$, and head circumference of $37.5 \mathrm{~cm}$. A diagnosis of athyrosis was made after physical examination and ${ }^{99 \mathrm{~m}} \mathrm{Tc}$ scintigraphy showed apparent absence of thyroid tissue. $T_{4}$ treatment was initiated on the 17 th $\mathrm{d}$ of life, and her growth and psychomotor development remained within normal limits. She was $3.3 \mathrm{yr}$ old when the propositus was born. Two brothers and both parents were in good health, except for depression in the father that required lithium therapy. The family originated in Morocco and all children were born in Belgium.

Inconsistent with the diagnosis of athyrosis (23), serum TG was in the high normal range at the time of diagnosis in both patients $(66 \mathrm{ng} /$ $\mathrm{ml}$ in propositus, $84 \mathrm{ng} / \mathrm{ml}$ in affected sister). Careful ultrasonography in the propositus revealed a hypoechogenic gland in normal position below the thyroid cartilage, whose transverse diameters were 5.2 and $4.9 \mathrm{~mm}$ for the left and right lobes, respectively, which corresponds to a very hypoplastic thyroid (24). Serum TG decreased over a 6-mo period while under $\mathrm{T}_{4}$ therapy. Treatment was interrupted for $6 \mathrm{wk}$ in the sister at age $3.7 \mathrm{yr}$ for investigative purposes. Physical examination revealed no palpable thyroid, whereas serum-free $\mathrm{T}_{4}$ became very low, $<0.2 \mathrm{ng} / \mathrm{dl}$, TSH increased to $186 \mathrm{mU} /$ liter, and TG remained unchanged at $2.9 \mathrm{ng} / \mathrm{ml}$. Like in her brother, ultrasonography showed a very hypoplastic gland in normal position, with transverse diameters of 5.6 and $4.6 \mathrm{~mm}$ for the left and right lobes, respectively.

Serum TG was found elevated at $53.7 \mathrm{ng} / \mathrm{ml}$ in the father, but was in the normal range at $17.1 \mathrm{ng} / \mathrm{ml}$ in the mother. TG levels in the unaffected brothers were 31.4 and $41 \mathrm{ng} / \mathrm{ml}$, which is in the normal range for children in our population (13). Serum TSH and free $\mathrm{T}_{4}$ were within normal limits in both parents and both unaffected brothers. Autoantibodies directed against TG, TPO/microsomal antigen, or the TSHr were not detected in the patients, nor in either parent or unaffected sibling. The parents consented to these studies. These data are summarized in Fig. 1.

Sequencing of the TSHr gene. DNA was extracted from peripheral blood using standard procedures. PCR amplification was designed to produce five overlapping fragments that cover the whole length of exon 10. Exons 1 through 9 were amplified individually using couples of intronic primers. The fragment encompassing the mutation identified in this family was generated using the following primers (positions 1567-1960): forward primer: $5^{\prime}$-tgtaaacgacggccagtctggtatgccatcaccttc-3'; reverse primer: 5'-caggaaacagctatgacctgagaggcttgttcagaatt- $3^{\prime}$, where the underlined sequences correspond to universal sequencing primers $(-21 \mathrm{M} 13$ and M13RP1, respectively).

PCR was performed in a $100 \mu \mathrm{l}$ final volume containing $1 \mu \mathrm{g}$ DNA, $50 \mathrm{mM} \mathrm{KCl}, 10 \mathrm{mM}$ Tris- $\mathrm{HCl}, \mathrm{pH} 8.3,2 \mathrm{mM} \mathrm{MgCl} 2,0.01 \%$
TSH, mU/l [.05-5]
2.01
1.80
3.93
490
1.34
$>130$
Free $\mathbf{T}_{4}, \mathrm{ng} / \mathrm{dl}[.8-2.0]$
1.5
0.9
1.4
0.37
1.4
Total T4, $\mu \mathrm{g} / \mathrm{dl}$ [5-12]
the absence of thyroid hormone treatment. Normal values are given in brackets, except for serum TG, for which normal values in our pop- ulation with borderline iodine in- take are as follows $(\mathrm{ng} / \mathrm{ml})$ : new- borns, 2-106; < $10 \mathrm{yr}, 2-65$; adults,
TG, ng/ml

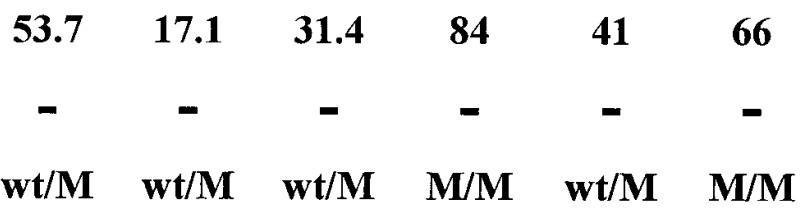
2-35. AutoAb, serum autoantibod- ies against TPO, TG, and the TSHr; - , below level of clinical signifi- cance; wt, wild-type TSHr sequence; $\mathrm{M}, \mathrm{Ala}_{553} \rightarrow \mathrm{Thr}(\mathrm{A} 553 \mathrm{~T})$ mutation as in Fig. 2.

Figure 1. Thyroid blood tests and genotypes in the family. The parents are second cousins and the propositus is indicated by the arrow. Solid symbols indicate congenital hypothyroidism with apparently absent thyroid gland on physical examination and ${ }^{99 \mathrm{~m}} \mathrm{Tc}$ isotopic scan. Blood tests were performed in the parents and four children. Values in affected siblings are at the time of diagnosis, and all measures are in 
gelatine, $0.2 \mathrm{mM}$ dNTP, $5 \mathrm{U}$ Taq Polymerase (GIBCO-BRL, Gaithersburg, MD), and $100 \mathrm{nM}$ of each primer. The annealing temperature was $50^{\circ} \mathrm{C}$. The PCR products were sequenced on both strands using the Thermosequenase fluorescent labeled primer cycle sequencing kit (RPN 2436; Amersham Corp., Arlington Heights, IL) according to the manufacturer's recommendations. Samples were loaded on a 373 Stretch Sequencing Instrument (Applied Biosystems, Inc., Foster City, CA) and mutations identified using the Factura and Sequence Navigator Software (ABI Advanced Biotechnologies, Inc., Columbia, MD).

Cloning and expression of the mutated TSHr. A CvnI-BsteII fragment (1604-2169) in the wild-type TSH receptor-pSVL construct was substituted by the mutant counterpart as previously described (7). Pfu enzyme was used to generate this fragment, in a $100 \mu \mathrm{l}$ final volume containing $200 \mathrm{ng}$ genomic DNA, $10 \mathrm{mM} \mathrm{KCl}, 20 \mathrm{mM}$ Tris- $\mathrm{HCl}$, $\mathrm{pH} 8.75,10 \mathrm{mM}\left(\mathrm{NH}_{4}\right)_{2} \mathrm{SO}_{4}, 2 \mathrm{mM} \mathrm{MgSO}{ }_{4}, 0.1 \%$ Triton X-100, 0.1 $\mathrm{mg} / \mathrm{ml} \mathrm{BSA}, 0.2 \mathrm{mM}$ dNTP, 5\% DMSO, $2.5 \mathrm{U}$ Pfu DNA Polymerase (Stratagene Inc., La Jolla, CA), and $0.5 \mu \mathrm{M}$ of each primer. The annealing temperature was $52^{\circ} \mathrm{C}$. The resulting constructs were verified by double stranded sequencing as described above.

COS-7 cells were grown in Dulbecco's modified Eagle's medium supplemented with $10 \%$ fetal bovine serum, $1 \mathrm{mM}$ sodium pyruvate, $100 \mathrm{IU} / \mathrm{ml}$ penicillin, $100 \mu \mathrm{g} / \mathrm{ml}$ streptomycin, and $2.5 \mu \mathrm{g} / \mathrm{ml}$ fungizone, and seeded at a density of 150,000 or 300,000 cells/3-cm dish. $1 \mathrm{~d}$ later, they were transfected (250 or $500 \mathrm{ng}$ DNA/150,000 or 300,000 cells, respectively) by the DEAE-Dextran method followed by a dimethylsulfoxide shock (25). To obtain a "standard curve" of expression, various amounts of the wild-type construct were mixed with pSVL vector or with the mutated construct at $500 \mathrm{ng}$ final DNA amount and transfected in parallel in COS-7 cells.

$2 \mathrm{~d}$ after transfection, triplicate dishes were used for flow immunocytofluorometry, cAMP determinations, and ${ }^{125} \mathrm{I}$-TSH binding studies; duplicate dishes were used for inositolphosphate determinations. Each experiment was repeated at least three times.

Binding and flow immunocytofluorometry studies. $2 \mathrm{~d}$ after transfection, cells were washed twice with $\mathrm{NaCl}$-free Hank's buffer supplemented with $280 \mathrm{mM}$ sucrose, $0.2 \%$ BSA, and $2.5 \%$ low fat milk, and were incubated at room temperature in fresh medium supplemented with 100,000 counts/ml ${ }^{125} \mathrm{I}-\mathrm{TSH}(35 \mu \mathrm{Ci} / \mu \mathrm{g}, 40 \mathrm{U} / \mathrm{mg}$ TRAK assays; BRAHMS diagnostica, Berlin, Germany) and various concentrations of unlabeled TSH. $4 \mathrm{~h}$ later, the cells were rinsed twice with chilled Hank's buffer and solubilized by $1 \mathrm{M} \mathrm{NaOH}$. Bound radioactivity was determined in a gamma scintillation counter. Under these conditions, the radioactivity nonspecifically bound to COS-7 cells expressing the TSH receptor (defined as the radioactivity bound to the dish in the presence of $100 \mathrm{mU} / \mathrm{ml}$ unlabeled TSH) was identical to that bound to mock-transfected cells. In the absence of a consensus about the bioactivity of pure bovine TSH, we have expressed all TSH or TSH receptor concentrations in milliunits/milliliter, assuming a 1:1 stoichiometry for TSH binding to its receptor. The competition binding curves have been fitted by nonlinear regression, assuming a single receptor site (26).

For flow immunocytofluorometry (FACS ${ }^{\circledR}$; Becton Dickinson \& Co., Mountainview, CA), cells were detached from the plates with PBS supplemented with $5 \mathrm{mM}$ each of EDTA and EGTA, and transferred into Falcon tubes (2052; Falcon Labware, Cockeysville, MD), centrifuged at $500 \mathrm{~g}$ at $4^{\circ} \mathrm{C}$ for $3 \mathrm{~min}$, and the supernatant was removed by inversion. In the nonpermeabilized cell assay, cells were immediately incubated with the antibody. In the permeabilized cell assay, cells were first fixed in 2\% PBS-PAF (Paraformaldehyde; UCB, Brussels, Belgium) for $10 \mathrm{~min}$ on ice, and thereafter incubated with $0.1 \%$ PBS-BSA- $0.2 \%$ Saponin (Sigma Chemical Co., St. Louis, MO) for $30 \mathrm{~min}$, and saponin-supplemented PBS buffer was used in all subsequent incubations. After incubation for $30 \mathrm{~min}$ at room temperature with $100 \mu \mathrm{l} 0.1 \%$ PBS-BSA containing the $2 \mathrm{C} 11 \mathrm{mAb}(10$ $\mu \mathrm{g} / \mathrm{ml}$ ), the cells were washed with $4 \mathrm{ml} 0.1 \%$ PBS-BSA, centrifuged as above, and incubated for $30 \mathrm{~min}$ on ice in the dark with fluorescein-conjugated gamma chain-specific goat anti-mouse IgG (Sigma
Chemical Co.) in the same buffer. The $2 \mathrm{C} 11 \mathrm{mAb}$ kindly provided by Dr. A.P. Johnstone (27) recognizes a linear epitope of the extracellular aminoterminus of the TSHr (VFFEEQ, residues 354-359). Propidium iodide $(10 \mu \mathrm{g} / \mathrm{ml})$ was used for detection of damaged cells, which were excluded from the analysis. Cells were washed once again and resuspended in $250 \mu \mathrm{l} 0.1 \%$ PBS-BSA. The fluorescence of 10,000 cells per tube was assayed by a FACScan Flow Cytofluorometer (Beckton Dickinson \& Co.).

Measurements of cAMP and inositolphosphates accumulation. For cAMP determination, cells were washed with isotonic KrebsRinger-Hepes buffer (KRH), pH 7.4. After preincubation in $\mathrm{KRH}$ at $37^{\circ} \mathrm{C}$ for $30 \mathrm{~min}$, cells were incubated in the same buffer supplemented with $25 \mu \mathrm{M}$ Rolipram (cAMP phosphodiesterase inhibitor, a gift from the Laboratory J. Logeais, Paris, France), in the absence of added agonist, or in the presence of various concentrations of bovine TSH (Sigma Chemical Co.) or $10 \mu \mathrm{M}$ forskolin (Calbiochem Corp., La Jolla, CA). The medium was removed after $60 \mathrm{~min}$ and $0.1 \mathrm{M} \mathrm{HCl}$ was added to the cells. The samples were dried overnight in a vacuum concentrator and intracellular cAMP, expressed as picomoles per dish, was measured in duplicate for each dish by ${ }^{3} \mathrm{H}$-cAMP assay system (code 432, TRK; Amersham Corp.).

For inositolphosphates (IPs) determination, cells were incubated with $20 \mu \mathrm{Ci}{ }^{3} \mathrm{H}$-inositol (code TRK.911; Amersham Corp.) per ml DMEM for $24 \mathrm{~h}$. The cells were then washed twice with KRH. After a preincubation in $\mathrm{KRH}$ supplemented with $10 \mathrm{mM} \mathrm{LiCl}$ at $37^{\circ} \mathrm{C}$ for $30 \mathrm{~min}$, cells were incubated at $37^{\circ} \mathrm{C}$ for $15 \mathrm{~min}$ within the same medium in the absence of added agonist, or in the presence of $100 \mathrm{mU} /$ $\mathrm{ml}$ bovine TSH or $0.1 \mathrm{mM}$ ATP. The medium was removed and the reaction was stopped by addition of ice cold $3 \% \mathrm{HClO}_{4} \cdot{ }^{3} \mathrm{H}$-labeled IPs were isolated and assayed by stepwise chromatography on AG1X8 resin (28). Cellular fragments on the dishes were dissolved with $1 \mathrm{M} \mathrm{NaOH}$ and counted as phosphatidylinositols. Results were expressed as a percentage of radioactivity incorporated in IPs (IP1 + IP2 + IP3) over the sum of radioactivity incorporated in IPs and phosphatidylinositols.

Computation of transfection efficiency and specific constitutive activity. Constitutive activity was determined for each construct using the following formula: $C_{\mathrm{e}}=\left[A_{\mathrm{n}}-Z(1-\mathrm{e})\right] / Z \mathrm{e}$, where $A_{\mathrm{n}}$ is the basal (no ligand added) cAMP value as measured experimentally, $Z$ is the basal cAMP value in mock (pSVL)-transfected cells, and e is the transfection efficiency as determined by FACS ${ }^{\circledR}$ Cytofluorometry assay, allowing for subtraction of ambient cAMP production by untransfected cells. $C_{\mathrm{e}}$ is thus the ratio between the cAMP level in cells expressing the receptor constructs over the cAMP level in the same number of cells transfected with the pSVL vector alone. $C_{\mathrm{e}} / R_{\mathrm{e}}$ normalizes $C_{\mathrm{e}}$ for the level of expression of each construct (see below). A measure of the relative constitutivity of the mutant receptor over the wild type is given by $F=C_{\mathrm{e}}$ mutant $/ C_{\mathrm{e}}$ wild type. This value does not account for the differences in expression of the mutants at the cell surface. It gives a measure of relative constitutivity, at the actual level of expression achieved by individual receptor constructs. An estimation of specific constitutive activity (SCA) (i.e., constitutive activity normalized to equal level of expression) is given by SCA $=F / R_{\mathrm{e}}$, where $R_{\mathrm{e}}$ is a measure of the expression of the mutant receptor relative to the wild type with $R_{\mathrm{e}}=$ (Mut-pSVL)/(WT-pSVL), the ratio between the fluorescence of cells transfected with the mutant and the wild-type receptor constructs, after subtraction of the background fluorescence displayed by mock transfected cells. The comparison of SCAs computed for each construct determines the relative constitutivity of molar amounts of the mutant over the wild type.

Statistics. Levels of significance were evaluated by a two-tailed unpaired Student's $t$ test, and $P<0.05$ was considered significant.

\section{Results}

Familial mutation of the TSH receptor. Considering the clinical picture consistent with TSH unresponsiveness and the fa- 


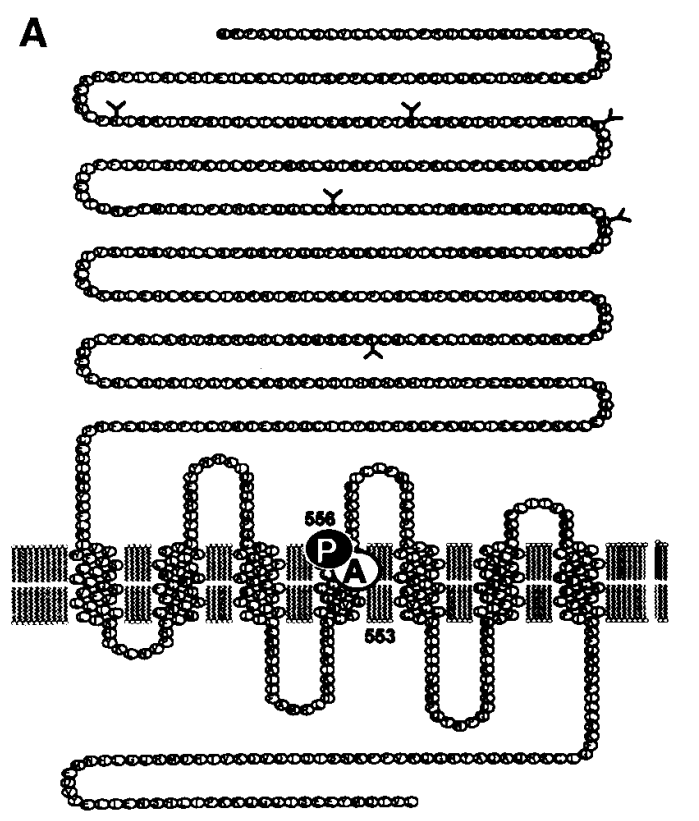

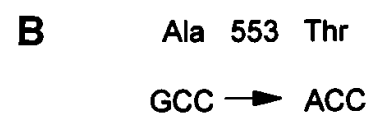

Normal control

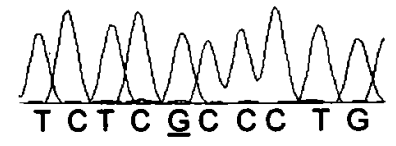

Father

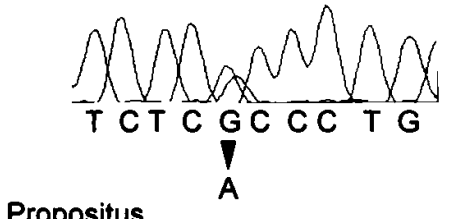

Propositus

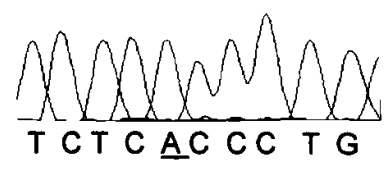

Figure 2. Familial mutation of the $\mathrm{TSHr}$ gene. $B$ shows results from direct sequencing of PCR-amplified genomic DNA from peripheral blood in a normal unrelated control subject, in the propositus' asymptomatic father, and in the propositus. It demonstrated a GCC $\rightarrow$ ACC mutation, affecting the alanine residue at position 553 (A553T), which was replaced by a threonine in the fourth putative transmembrane domain of the TSHr protein as schematized in $A$. Also represented in $A$ is the location of the P556L mutation identified in the hyt/ hyt mouse (see text). The genotypes of our patients and family are mentioned in Fig. 1. milial recurrence, we investigated by direct sequencing the TSHr gene amplified from peripheral blood genomic DNA. As sole anomaly, we identified a GCC $\rightarrow$ ACC mutation (Fig. 2 $B$ ) affecting the alanine residue at position 553, which was replaced by a threonine in the putative polypeptide chain (A553T). The $\mathrm{Ala}_{553}$ amino acid residue is highly conserved among the receptors for glycoprotein hormones of all mammalian species studied $(2-5,16)$, lending support to a pathogenic role of mutation A553T. Consistent with autosomal recessive transmission of the disease, the mutation was found homozygous in the propositus and his affected sister, whereas it was heterozygous in both parents. The two unaffected brothers were found to be heterozygous carriers of the mutation as well. The genotypes are mentioned in Fig. 1.
Expression of the mutated receptor. The functional characteristics of the mutated receptor were studied by transient expression in COS-7 cells. Cells transfected with a cDNA construct encoding the wild-type receptor or the empty $\mathrm{pSVL}$ vector were used as controls. Levels of expression at the cell surface were assessed by flow cytometry using a monoclonal antibody recognizing the linear epitope VFFEEQ (residues 354-359) $(27,29)$ of the extracellular aminoterminal domain. It demonstrated an extremely low level of expression for the mutant (Fig. 3). The comparison of saponin-permeabilized (Fig. 3 $B$ ) and nonpermeabilized (Fig. $3 A$ ) cells showed that synthesis of the different constructs was quantitatively similar, which indicated that the mutant and wild-type receptors were equally recognized by the monoclonal antibody and that the low level

A
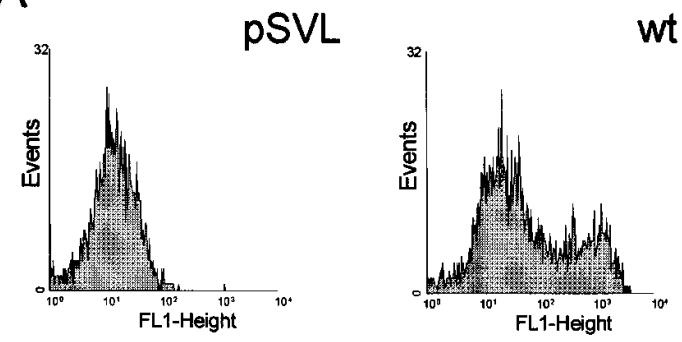

wt TSHr

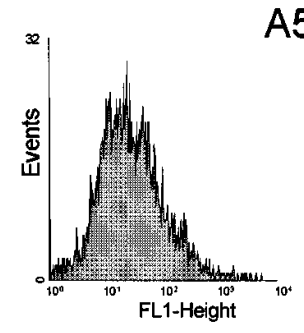

A553T

B
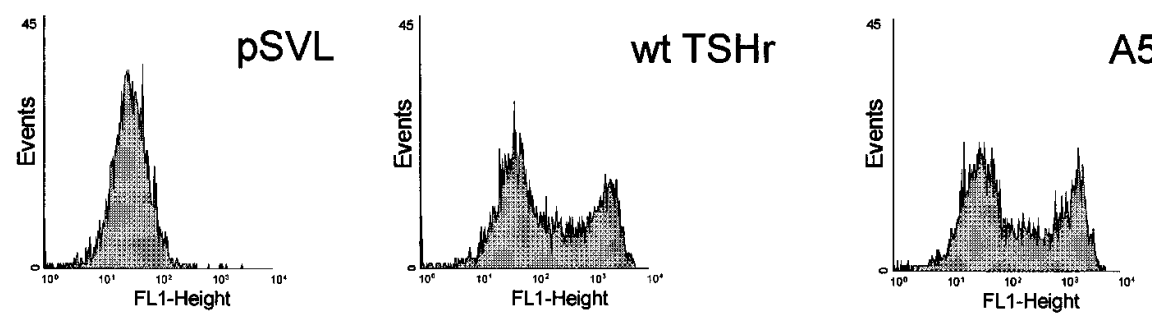

Figure 3. Expression analysis of the A553T mutant by flow immunocytometry. Fluorescence intensity is expressed in arbitrary units, as a function of cell number (10,000 propidium iodide-gated cells) plotted on a logarithmic scale (see Methods). (A) Nonpermeabilized cells assayed after transfection with pSVL vector $(p S V L)$, wild-type TSHr construct ( wt TSHr), or A553T mutant TSHr construct $(A 553 T)$. (B) Saponin-permeabilized cells transfected identically. Compared with pSVL-transfected cells, the shift in fluorescence of cells transfected with a receptor construct reflects the amount of receptor expressed at the cell surface $(A)$ or present within the cell $(B)$. 


\begin{tabular}{|lll|}
\hline- wtTSHr & Rt $1.58 \mathrm{mU} / \mathrm{ml}$ & $\mathrm{Kd} 1.26 \mathrm{mU} / \mathrm{ml}$ \\
$\square-$ wtTSHr, diluted & Rt $0.06 \mathrm{mU} / \mathrm{ml}$ & $\mathrm{Kd} 0.35 \mathrm{mU} / \mathrm{ml}$ \\
$-\triangle$ A $553 T$ & Rt $0.03 \mathrm{mU} / \mathrm{ml}$ & $\mathrm{Kd} 0.21 \mathrm{mU} / \mathrm{ml}$ \\
\hline
\end{tabular}

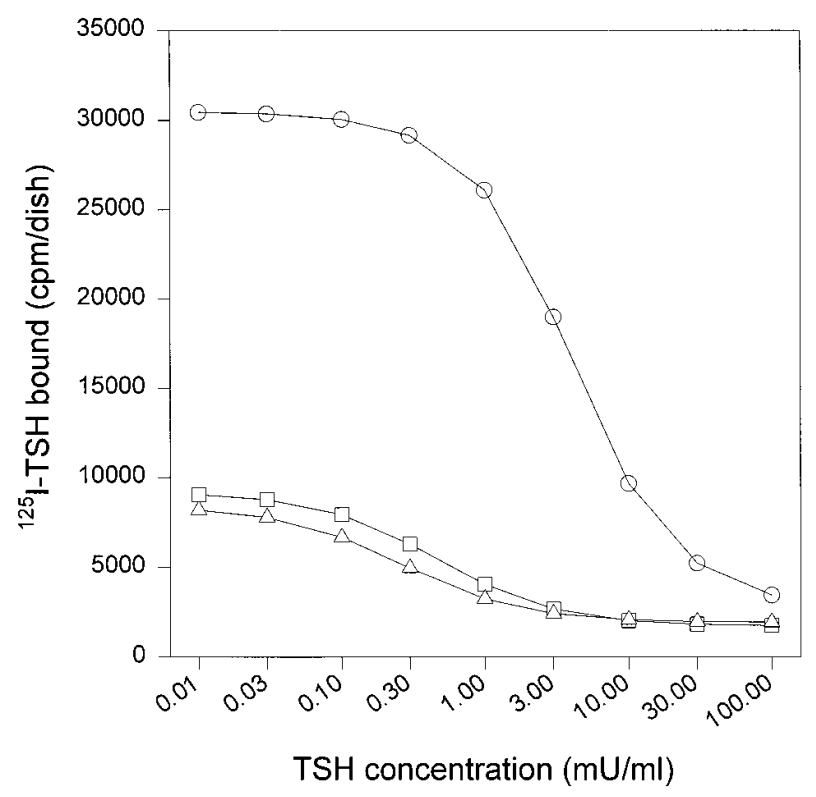

Figure 4. Binding studies. ${ }^{125}$ I-TSH binding curves from a representative experiment with wild-type ( $w t$ TSHr) and mutated (A553T) TSHr constructs expressed in COS- 7 cells $(300,000$ cells/dish) transfected with $500 \mathrm{ng}$ construct DNA. Results are expressed as total number of receptors $(R t, m U / m l)$ and apparent dissociation constant $(K d, m U / m l)$. To compare wild-type and mutated constructs at a comparable level of expression, triplicate sets of dishes were also transfected with decreasing amounts of the wild-type construct. Results are shown from transfection with diluted wtTSHr DNA (10 ng mixed with pSVL vector DNA at $500 \mathrm{ng}$ ), yielding a low level of expression close to mutant, with a concomitant decrease in apparent $K_{\mathrm{d}}$.

of expression at the cell surface resulted from a posttranslational event, perhaps a defect in the folding of the receptor resulting in abnormal routing to the plasma membrane. The expression of the mutant was identical when transfected cells were incubated at $30^{\circ} \mathrm{C}$ for $48 \mathrm{~h}$ before the functional assays (data not shown).

Binding studies were congruent with the FACS ${ }^{\circledR}$ analysis, and showed very low expression of TSH binding sites at the plasma membrane of cells transfected with the mutant construct, with an $R_{\mathrm{t}}$ value of $0.03 \mathrm{mU} / \mathrm{ml}$ vs. $1.58 \mathrm{mU} / \mathrm{ml}$ for wild type in a representative experiment (Fig. 4). The observed dissociation constant of the mutant receptor was significantly smaller than wild type $(0.21 \mathrm{mU} / \mathrm{ml}$ vs. $1.26 \mathrm{mU} / \mathrm{ml}$, Fig. 4$)$, which was confirmed in three independent experiments yielding values of $0.22 \pm 0.01$ for $K_{\mathrm{d}}$ and $0.018 \pm 0.01 \mathrm{mU} / \mathrm{ml}$ for $R_{\mathrm{t}}$ (means $\pm \mathrm{SD}$ ). This may simply reflect the decrease in apparent $K_{\mathrm{d}}$ that parallels the decrease in TSHr expression, as recently reported in stably transfected $\mathrm{CHO}$ cells (30), and as we observed in COS-7 cells (our unpublished observations). To exclude an additional effect of the mutation on the $K_{\mathrm{d}}$, we performed binding studies on cells transfected with decreasing amounts of the wild-type receptor construct diluted in pSVL vector: when expressed at comparable levels, both constructs displayed comparable apparent affinities (Fig. 4).

Activity of the mutated receptor on production of second messengers. When overexpressed in COS-7 cells, the mutant receptor displayed a partial ability to stimulate cAMP accumulation in response to TSH (Fig. $5 \mathrm{~A}$ ). No systematic differences were observed as compared with the wild-type receptor for both $\mathrm{EC}_{50}(\sim 0.3 \mathrm{mU} / \mathrm{ml})$ and maximally active TSH concentration $(\sim 10 \mathrm{mU} / \mathrm{ml})$ (data not shown). In the absence of added agonist, the mutated receptor elicited a detectable level of cAMP accumulation that was smaller than in cells transfected with the wild-type receptor. As FACS ${ }^{\circledR}$ data allowed correction for transfection and expression efficiencies, we could compute the SCA as described in Methods. If the SCA of the wild type is arbitrarily put to 1, the A553T mutant displayed an SCA of $0.92 \pm 0.57$ (mean \pm SD) in five independent experiments. In spite of the dispersion of the values, which is essentially accounted for by the low expression of the mutated construct, we conclude that the mutant displays a constitutive cAMP stimulation activity similar to the wild-type receptor, in addition to its conserved cAMP response to TSH.

To confirm the recessive behavior of the mutation, we addressed the possibility of a dominant negative effect by cotransfection of the wild-type and the mutant constructs in various proportions, versus the wild-type construct mixed with pSVL vector to the same final amount of transfected DNA. For both the $\mathrm{FACS}^{\circledast}$ expression assay and the cAMP production assay, cotransfected cells behaved identically as the cells transfected with the wild-type receptor construct diluted in pSVL vector DNA (data not shown).

The mutated receptor was tested for its activity on the phosphatidylinositol-diacylglycerol regulatory pathway (Fig. 5 $B)$. In the absence of added agonist, we observed no significant stimulation of IP accumulation with the mutated as compared with the wild-type receptor. Stimulation by $100 \mathrm{mU} / \mathrm{ml} \mathrm{TSH}$ elicited no response from the mutated construct as compared with the mock (pSVL)-transfected cells.

\section{Discussion}

Athyrosis is rarely, if ever, familial, and its cause has remained elusive in spite of its relatively high frequency. We show here that a genetic defect of the TSHr can cause a syndrome of apparent athyrosis that is transmitted as autosomal recessive.

The $\mathrm{Ala}_{553} \rightarrow$ Thr missense mutation we identified in the TSHr gene affects a highly conserved amino acid residue, and cosegregates with the disease in this family. It is located in the fourth putative transmembrane domain of the receptor (Fig. 2 $A$ ), and is reminiscent of the closely located Pro $_{556} \rightarrow$ Leu (P556L) mutation of the murine TSHr, described in the hypothyroid hyt/hyt mouse, an animal model for TSH unresponsiveness (16). This mouse strain exhibits autosomal recessive congenital hypothyroidism with a normally located hypoplastic thyroid gland, as found in our patients. TSH unresponsiveness in these mice was found to result from defective TSH binding to a mutated receptor, which was apparently present at the plasma membrane (17). Unlike the mouse model however, TSH unresponsiveness in our patients is explained by the extremely low expression at the cell surface (Fig. $3 A$ ) of the A553T mutant receptor, in spite of synthesis in normal amounts (Fig. $3 \mathrm{~B}$ ).

Expression of TSH receptor constructs in COS-7 cells dif- 

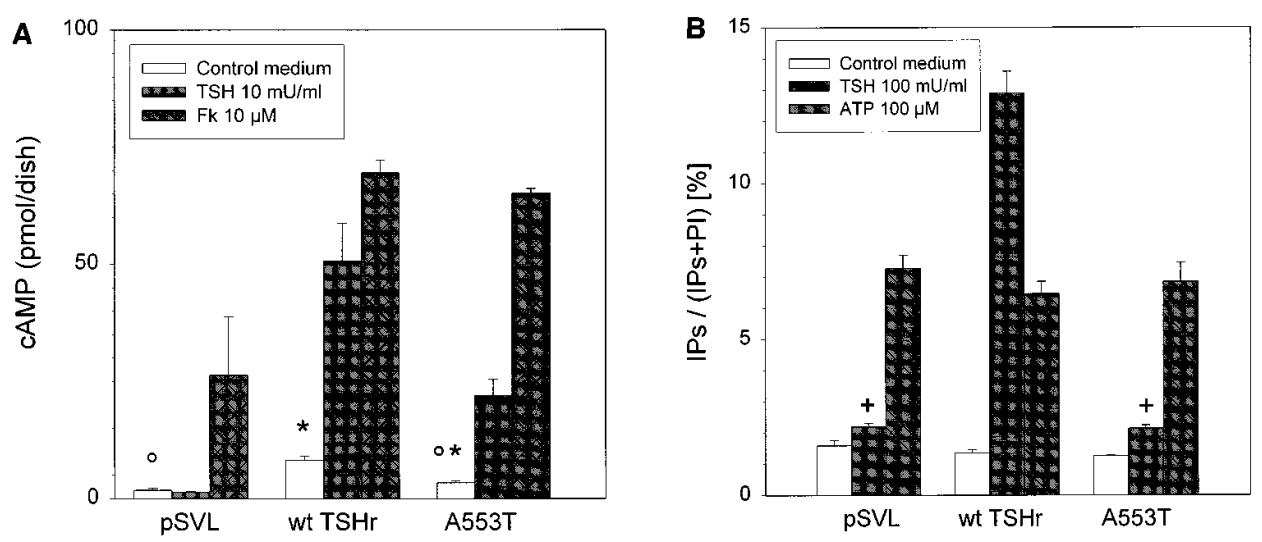

Figure 5. cAMP and inositolphosphates production in COS-7 cells. COS-7 cells ( 300,000 cells/dish) were transfected with $500 \mathrm{ng}$ pSVL vector DNA (pSVL), wild-type TSHr construct (wt TSHr), or A553T mutant TSHr construct $(A 553 T)$. (A) cAMP accumulation determined in cells maintained in unsupplemented control medium (open), under stimulation by $10 \mathrm{mU} / \mathrm{ml} \mathrm{TSH}$ (gray) or $10 \mu \mathrm{M}$ forskolin (Fk; crosshatched gray). Values are from a representative experiment and are means $\pm \mathrm{SD}$ of triplicate cAMP assays. The differences in basal cAMP production were significant at $P=0.0012(*)$ between mutant and wild-type constructs, and at $P=0.01$ (o) between mutant and pSVL control (mock-transfected cells). (B) Accumulation of IPs determined in unsupplemented control medium (open), under stimulation by $100 \mathrm{mU} / \mathrm{ml} \mathrm{TSH}$ (gray) or $100 \mu \mathrm{M}$ ATP (hatched gray). Results are expressed as the percentage of radioactivity incorporated in IPs over the sum of radioactivity in IPs and phosphatidylinositols $([\mathrm{IP} 1+$ IP2 + IP3]/[IPs + PI $]) \times 100$. Values are means \pm range from a representative experiment performed in duplicate dishes. No significant IP production was observed from the mutant in control medium nor under maximal TSH stimulation. ${ }^{+} P=0.477$.

fers from the natural expression in thyrocytes in many aspects: (a) the level of expression is probably two to three orders of magnitude higher, as the consequence of transcription from a high number of copies containing a strong promoter; $(b)$ the complement and concentrations of $\mathrm{G}$ proteins are likely to be different; $(c)$ the characteristics of the membrane system and routing of membrane proteins are also different in a nonpolarized cell as opposed to the polarized thyrocyte. Despite these limitations, and perhaps because of some of them, overexpression of the A553T mutant in COS-7 cells provides pertinent information on structure/function relationships that add to the current molecular understanding of the TSHr, but whose in vivo relevance is unclear. The small number of receptors reaching the membrane seem to behave quite normally in terms of TSH binding and sensitivity to hormone for adenylyl cyclase stimulation. The apparent decrease in $K_{\mathrm{d}}$ is likely to result from the small number of receptors inserted correctly in the membrane (30), as this parameter normalizes when the wild-type and mutant receptors are expressed at similar levels (Fig. 4). The mechanism responsible for this effect is not understood, but it has also been observed for the PTH/PTHRP receptor (31). That the A553T receptor is competent for normal coupling to Gs is further indicated by its specific constitutive activity for cAMP generation, which is comparable with the wild type. Interestingly, the P556L mutation of the hyt/hyt mouse also displays constitutive activity. However, in this case, unresponsiveness to TSH must result from a structural defect since the receptor has been shown to reach the plasma membrane of transfected COS cells (17). As stated above, overexpression in COS-7 cells may nevertheless not reliably reflect the behavior of the TSHr in the thyrocyte, and the significance of the relatively robust residual cAMP production in COS-7 cells is unclear. If it participates in the observed phenotype, our findings may indicate that the blood levels of TSH sustained by our patients are limiting with regard to thyroid growth, as they remained comparable with the $\mathrm{EC}_{50}$ of the mutant $(0.3 \mathrm{mU} / \mathrm{ml})$, which is much smaller than the pharmacological concentrations used on COS-7 cells $(10$ or $100 \mathrm{mU} / \mathrm{ml})$ for maximal stimulation, and as human TSH is $5-10$ times less potent on the human TSHr than the bovine TSH used in this study (32).

Although competent for coupling to Gs, the A553T mutant appears to have lost the capability to activate the phospholipase $\mathrm{C}$-dependent regulatory pathway (Fig. $5 \mathrm{~B}$ ). Dissociation of coupling to $\mathrm{Gs}$ and $\mathrm{Gq}$ has been observed previously in spontaneous TSHr mutants (8) and site-directed mutagenesis experiments (10). It agrees with a current model for $\mathrm{G}$ protein-coupled receptor activation, implying the existence of multiple discrete activated conformations.

The high TG in the patients at the time of diagnosis is surprising and not easily explained in the context of a very hypoplastic gland and congenital hypothyroidism (23). Apart from trivial causes of error and cross-reactivity with an unsuspected antigen in the TG assay, our patients show that significant expression of the TG gene can take place in vivo in spite of complete or near-complete TSH unresponsiveness. These findings may be confronted with the current knowledge of thyroid organogenesis and thyroid-specific gene expression. From the available evidence, it seems that development and migration of the embryonic thyroid in front of the trachea is independent of stimulation by TSH. Indeed, expression of thyroid-specific genes, including TG,TPO, and the TSHr, is subsequent to the observation of an in-place thyroid rudiment (33), which is believed to result from the interplay of at least three transcription factors, TTF1, TTF2, and Pax8 (34). However, it is tempting to suggest that normal TSHr function may be required to achieve a fully differentiated thyroid phenotype. The observation of cytological abnormalities in hyt/hyt mice, including overdistension of the endoplasmic reticulum, is compatible with such hypotheses (35). The disproportionately high plasma TG levels (considering the small size of the patients' thyroids) could result from incomplete polarization of thyrocytes, abnormal routing of TG due to accumulation of misfolded mutant TSHr in the rough endoplasmic reticulum, or from intercellular leakage from dysplastic follicles. Testing of these hypotheses would require a biopsy of the thyroid from our patients, which we consider unethical.

The observed decrease and normalization of TG during $\mathrm{T}_{4}$ 
therapy is even more difficult to explain. It may simply correspond to the age-related decrease of serum TG observed in normal children from our population with borderline iodine intake (13). Alternatively, it is conceivable that irreversible full maturation of the thyroid could be normally dependent on autostimulation by thyroid hormones. Of note, TG levels did not increase when $T_{4}$ treatment was interrupted in the affected sister, in contrast with TSH that reached very high levels.

Unresponsiveness to TSH due to TSHr defects may represent a sizable subset of congenital hypothyroidism. It is probably rare even in the subgroup with familial occurrences of apparently absent thyroid tissue, as shown by the absence of any $\mathrm{TSHr}$ mutations in a small series of patients with familial TSH unresponsiveness in previous studies (21). This leaves room for other, still unidentified genetic defects. The unexpectedly high serum TG levels in our patients suggest that measuring TG in all newborns diagnosed with hypothyroidism may help delineate further the etiologies of congenital thyroid malfunction in the future.

\section{Acknowledgments}

We thank Dr. S. Costagliola for help with FACS ${ }^{\circledR}$ studies, Dr. P. Bergmann for TG measurements, Dr. P. Bourdoux for neonatal TSH screening, Dr. F. Ziereisen for ultrasound examinations, and M. Nguyen for technical assistance. The $2 \mathrm{C} 11 \mathrm{mAb}$ is a generous gift from Dr. A.P. Johnstone.

L. Duprez is a Fellow of the Belgian Fonds National de la Recherche Scientifique.

\section{References}

1. Vassart, G., J.E. Dumont, and S. Refetoff. 1995. Thyroid disorders. In The Metabolic and Molecular Bases of Inherited Disease., 7th ed. C.R. Scriver, A.L. Beaudet, W.S. Sly, and D. Valle, editors. McGraw-Hill, Inc., New York. 2917-2918.

2. Parmentier, M., F. Libert, C. Maenhaut, A. Lefort, C. Gerard, J. Perret, J. Van Sande, J.E. Dumont, and G. Vassart. 1989. Molecular cloning of the thyrotropin receptor. Science (Wash. DC). 246:1620-1622.

3. Nagayama, Y., K.D. Kaufman, P. Seto, and B. Rapoport. 1989. Molecular cloning, sequence and functional expression of the cDNA for the human thyrotropin receptor. Biochem. Biophys. Res. Commun. 165:1184-1190.

4. Libert, F., A. Lefort, C. Gerard, M. Parmentier, J. Perret, M. Ludgate, J.E. Dumont, and G. Vassart. 1989. Cloning, sequencing and expression of the human thyrotropin (TSH) receptor: evidence for binding of auto-antibodies. Biochem. Biophys. Res. Commun. 165:1250-1255.

5. Misrahi, M., H. Loosfelt, M. Atger, S. Sar, A. Guiochon-Mantel, and E. Milgrom. 1990. Cloning, sequencing and expression of human TSH receptor. Biochem. Biophys. Res. Commun. 166:394-403.

6. Gross, B., M. Misrahi, S. Sar, and E. Milgrom. 1991. Composite structure of the human thyrotropin receptor gene. Biochem. Biophys. Res. Commun. 177: 679-687.

7. Parma, J., L. Duprez, J. Van Sande, P. Cochaux, C. Gervy, J. Mockel, J.E. Dumont, and G. Vassart. 1993. Somatic mutations in the thyrotropin receptor gene cause hyperfunctioning thyroid adenomas. Nature (Lond.). 365:649-651.

8. Parma, J., J. Van Sande, S. Swillens, M. Tonacchera, J. Dumont, and G. Vassart. 1995. Somatic mutations causing constitutive activity of the thyrotropin receptor are the major cause of hyperfunctioning thyroid adenomas: identification of additional mutations activating both the cyclic AMP and inositol phosphate-Ca cascades. Mol. Endocrinol. 9:725-733.

9. Duprez, L., J. Parma, J. Van Sande, A. Allgeier, J. Leclere, C. Schvarts, M.J. Delisle, M. Decoulx, J. Orgiazzi, J.E. Dumont, and G. Vassart. 1994. Germline mutations in the thyrotropin receptor gene cause non-autoimmune autosomal dominant hyperthyroidism. Nat. Genet. 7:396-401.

10. Kosugi, S., F. Okajima, T. Ban, A. Hidaka, A. Shenker, and L.D. Kohn. 1994. Substitutions of different regions of the third cytoplasmic loop of the TSH receptor have selective effects on constitutive, TSH-, and TSH receptor autoantibody-stimulated phosphoinositide and cAMP signal generation. Mol. Endocrinol. 7:1009-1020.

11. Sunthornthepvarakul, T., M. Gottschalk, Y. Hayashi, and S. Refetoff. 1995. Resistance to thyrotropin caused by mutations in the thyrotropin receptor gene. N. Engl. J. Med. 323:155-160.
12. De Roux, N., M. Misrahi, R. Brauner, M. Houang, J.C. Carel, M. Granier, Y. Le Bouc, N. Ghinea, J.E. Toublanc, and E. Milgrom. 1996. Four families with loss of function mutations of the thyrotropin receptor. J. Clin. Endocrinol. Metab. 81:4229-4235.

13. Delange, F., and P. Czernichow. 1993. Thyroid hormones, biochemistry and physiology. In Pediatric Endocrinology, 2nd ed. J. Bertrand, R. Rappaport, and P.C. Sizonenko, editors. Williams and Wilkins, Baltimore, MD. 242-251.

14. Abramowicz, M.J., H.M. Targovnik, V. Varela, P. Cochaux, L. Krawiec, M.A. Pisarev, F.V.E. Propato, G. Juvenal, H.A. Chester, and G. Vassart. 1992. Identification of a mutation in the coding sequence of the human thyroid peroxidase gene causing congenital goiter. J. Clin. Invest. 90:1200-1204.

15. Beamer, W.G., E.M. Eicher, L.J. Maltais, and J.L. Southard. 1981. Inherited primary hypothyroidism in mice. Science (Wash. DC). 212:61-63.

16. Stein, S.A., E.L. Oates, C.R. Hall, R.M. Grumbles, L.M. Fernandez, N.A. Taylor, D. Puett, and S. Jin. 1994. Identification of a point mutation in the thyrotropin receptor of the hyt/hyt hypothyroid mouse. Mol. Endocrinol. 8:129-138.

17. Gu, W.X., G.G. Du, P. Kopp, A. Rentoumis, C. Albanese, L.D. Kohn, L.D. Madison, and J.L. Jameson. 1995. The thyrotropin (TSH) receptor transmembrane domain mutation (Pro556-Leu) in the hypothyroid hyt/hyt mouse results in plasma membrane targeting but defective TSH binding. Endocrinology. 136:3146-3153.

18. Standbury, J.B., P. Rocmans, U.K. Buhler, and Y. Ochi. 1968. Congenital hypothyroidism with impaired thyroid response to thyrotropin. N. Engl. J. Med. 279:1132-1136.

19. Codaccioni, J.L., P. Carayon, M. Michel-Bechet, F. Foucault, G. Lefort, and H. Pierron. 1980. Congenital hypothyroidism associated with thyrotropin unresponsiveness and thyroid cell membrane alterations. J. Clin. Endocrinol. Metab. 50:932-937.

20. Takamatsu, J., M. Nishigawa, H. Masateru, and N. Ohsawa. 1993. Familial unresponsiveness to thyrotropin by autosomal recessive inheritance. $J$. Clin. Endocrinol. Metab. 77:1569-1573.

21. Takeshita, A., Y. Nagayama, S. Yamashita, J. Takamatsu, N. Ohsawa, H. Maesaka, K. Tachibana, E. Tokuhiro, K. Ashizawa, N. Yokoyama, and S. Nagataki. 1994. Sequence analysis of the thyrotropin (TSH) receptor gene in congenital primary hypothyroidism associated with TSH unresponsiveness. Thyroid. 4:255-259.

22. Bibermann, H., H. Krude, C. Thiede, D. Kotulla, and A. Gruters. 1996. Sporadic congenital hypothyroidism due to compound heterozygosity for two mutations of the coding sequence of the thyrotropin receptor gene. 10th International Congress of Endocrinology. (Abstr.)

23. Czernichow, P., M. Schlumberger, R. Pomarede, and P. Fragu. 1983. Plasma thyroglobulin measurements help determine the type of thyroid defect in congenital hypothyroidism. J. Clin. Endocrinol. Metab. 56:242-245.

24. Chanoine, J.P., M. Toppet, R. Lagasse, M. Spehl, and F. Delange. 1991. Determination of thyroid volume by ultrasound from the neonatal period to late adolescence. Eur. J. Pediatr. 150:395-399.

25. Lopata, M.A., D.N. Cleveland, and B. Solmer-Wess. 1984. High level transient expression of a chloramphenicol acetyl transferase gene by DEAEdextran mediated DNA transfection coupled with a dimethyl sulfoxide or glycerol shock treatment. Nucleic Acids. Res. 12:5707-5711.

26. Swillens, S. 1995. Interpretation of binding curves obtained with high receptor concentrations: practical aid for computer analysis. Mol. Pharmacol. 47: 1197-1203.

27. Johnstone, A.P., J.C. Cridland, C.R. DaCosta, E. Harfst, and P.S. Shepherd. 1994. Monoclonal antibodies that recognize the native human thyrotropin receptor. Mol. Cell. Endocrinol. 105:R1-R9.

28. Berridge, M.J. 1983. Rapid accumulation of inositol trisphosphate reveals that agonists hydrolyse polyphosphoinositides instead of phosphatidylinositol. Biochem. J. 212:849-858.

29. Van Sande, J., C. Massart, S. Costagliola, A. Allgeier, F. Cetani, G. Vassart, and J.E. Dumont. 1996. Specific activation of the thyrotropin receptor by trypsin. Mol. Cell. Endocrinol. 119:161-168.

30. Chazenbalk, G.D., A. Kakinuma, J.C. Jaume, S.M. McLachlan, and B. Rapoport. 1996. Evidence for negative cooperativity among human thyrotropin receptors overexpressed in mammalian cells. Endocrinology. 137:4586-4591.

31. Bringhurst, F.R., H. Juppner, J. Guo, P. Urena, J.T. Potts, Jr., H.M. Kronenberg, A.B. Abou-Samra, and G.V. Segre. 1993. Cloned, stably expressed parathyroid hormone $(\mathrm{PTH}) / \mathrm{PTH}$-related peptide receptors activate multiple messenger signals and biological responses in LLC-PK 1 kidney cells. Endocrinology. 132:2090-2098.

32. Szkudlinski, M.W., N.G. Teh, M. Grossman, J.E. Tropea, and B.D. Weintraub. 1996. Engineering human glycoprotein hormone superactive analogues. Nat. Biotechnol. 14:1257-1263.

33. Kimura, S., Y. Hara, T. Pineau, P. Fernadez-Salguero, C.H. Fox, J.M. Ward, and F.J. Gonzalez. 1996. The T/ebp null mouse: thyroid-specific enhancer-binding protein is essential for the organogenesis of the thyroid, lung, ventral forebrain, and pituitary. Genes Dev. 10:60-69.

34. Damante, G., and R. Di Lauro. 1994. Thyroid-specific gene expression. Biochim. Biophys. Acta. 1218:255-266.

35. Stein, S.A., D.R. Shanklin, L. Krulich, M.G. Roth, C.M. Chubb, and P.M. Adams. 1989. Evaluation and characterization of the hyt/hyt hypothyroid mouse. Neuroendocrinology. 49:509-519. 